\title{
A review of betanodavirus vaccination as preventive strategy to viral nervous necrosis (VNN) disease in grouper
}

\author{
Hazreen-Nita M. ${ }^{1,2}$ - Azila A. ${ }^{3} \cdot$ Mukai Y. ${ }^{1}$ - Firdaus-Nawi M. ${ }^{1} \cdot$ Nur-Nazifah M. ${ }^{1}$
}

Received: 9 February 2019 / Accepted: 31 May 2019 / Published online: 19 June 2019

(C) Springer Nature Switzerland AG 2019

\begin{abstract}
Viral disease outbreak is the most serious issue as it may cause severe losses to farmers as well as to economy in the marine industry worldwide. Among fish viral diseases, betanodavirus is a significant pathogen that causes viral nervous necrosis (VNN) and can result in mass mortalities to fish culture especially at larval stages. In Malaysia, betanodavirus had been isolated from groupers, seabass, red snappers, and golden pomfret. Recently, inconsistent seed supply is observed due to viral infection at larval stages which limits the growth of fish culture. Therefore, seeds of grouper are often imported from neighboring countries such as Indonesia by farmers. Strict importation regulations should be practiced as the importation of fish seeds may become a possible source of the virus entering the country. It is a challenge to track farmers who are affected by the disease in order to segregate or eliminate the VNN carrier spawners. This scenario had resulted in incomplete destruction of diseased fish population and leads to re-occurrence of the disease at the early stage of grouper. This situation warrants immediate attention to develop promising prevention strategies such as a new vaccine which is very important and could work effectively with better farm management approaches. This article discusses the occurrence of viral nervous necrosis (VNN) disease in Malaysia and reviews possible preventive measures via vaccination to combat the disease.
\end{abstract}

Keywords Grouper - Betanodavirus · Viral nervous necrosis $(\mathrm{VNN}) \cdot$ Vaccination $\cdot$ Fish disease

\section{Abbreviations}

VNN Viral nervous necrosis

VER Viral encephalopathy retinopathy

Nur-Nazifah M.

nurnazifah@iium.edu.my

1 Kulliyyah of Science, International Islamic University Malaysia, Bandar Indera Mahkota, 25200 Kuantan, Pahang, Malaysia

2 Faculty of Agro-Based Industry, University Malaysia Kelantan, Jeli Campus, 17600 Jeli, Kelantan, Malaysia

3 National Fish Health Research Centre, Batu Maung, 11960 Penang, Malaysia 


$\begin{array}{ll}\text { NNV } & \text { Nervous necrosis virus } \\ \text { dpi } & \text { Day post-injection } \\ \text { RNA } & \text { Ribonucleic acid } \\ \text { DNA } & \text { Deoxyribonucleic acid } \\ \text { SJNNV } & \text { Striped jack nervous necrosis virus } \\ \text { TPNNV } & \text { Tiger puffer nervous necrosis virus } \\ \text { BFNNV } & \text { Barfin flounder nervous necrosis virus } \\ \text { RGNNV } & \text { Red-spotted grouper nervous necrosis virus } \\ \text { TNV } & \text { Turbot betanodavirus strain } \\ \text { ORF } & \text { Open reading frames } \\ \text { cp } & \text { Capsid protein } \\ \text { RdRps } & \text { RNA-dependent RNA polymerase } \\ \text { IHC } & \text { Immunohistochemistry } \\ \text { RT-PCR } & \text { Reverse transcription polymerase chain reaction } \\ \text { ELISA } & \text { Enzyme-linked immunosorbent assays } \\ \text { TEM } & \text { Transmission electron microscopy } \\ \text { RPS } & \text { Relative percentage survival } \\ \text { IM } & \text { Intramuscular } \\ \text { IHNV } & \text { Infectious hematopoietic necrosis virus } \\ \text { VHS } & \text { Viral hemorrhagic septicemia } \\ \text { CFPS } & \text { Cell-free protein synthesis } \\ & \end{array}$

\section{Introduction}

Malaysia is known as a major tropical marine fish producer in the world after China, Indonesia, Thailand, and Vietnam. Local marine aquaculture production has been dominated by species such as snapper (Lutjanus spp.), sea bass (Lates calcarifer), and grouper (Epinephelus spp.) which were recorded at 5536 tonnes, 15,025 tonnes, and 6156 tonnes respectively, with an estimated wholesale value of RM 117.94 million, RM 249.68 million, and RM 219.46 million respectively (AFS 2016). To date, marine aquaculture in Malaysia is growing with the introduction of new cultured marine fish species including Asian seabass (L. calcarifer), brown-marbled grouper (Epinephelus fuscoguttatus), and golden pompano (Ransangan et al. 2013). The major limitation in marine aquaculture industry for rapid expansion in Malaysia is the shortage of fish seeds which has led to fish fingerling importation from neighboring countries such as Thailand, Taiwan, and Indonesia (Ransangan et al. 2013). In previous documentation, betanodavirus was reported to infect humpback grouper and brown-marbled grouper in Indonesia. Ransangan et al. (2013) had received twice specimen of humpback grouper and brown-marbled grouper which those specimen that was received in July 2008 were detected as viral nervous necrosis (VNN)-positive, while specimen received later in April 2009 were virus-free (Ransangan et al. 2013). Therefore, fish importation practice with proper quarantine requires serious attention and concern as it may become a consequential source of disease. In fact, the viral disease can rapidly spread through horizontal and vertical transmission especially in aquaculture.

Grouper production is often limited by disease outbreak which occurs throughout the production cycle (Bondad-Reantaso et al. 2005; Muroga 2001). One of the common diseases in grouper is viral nervous necrosis ( $\mathrm{VNN}$ ) caused by betanodavirus that may lead to mass 
mortality in many marine fish species. Affected fish will swim near to the surface and then sink to the bottom while some may show abnormal behavior such as lethargy, spiral swimming, and change in pigmentation. Besides, diseased fish may also develop a bloated belly (Nagasawa and Cruz-Lacierda 2004). Clinical signs of this disease could be observed by 15-day postinjection (dpi) while cumulative mortalities might rise to $100 \%$ at 30 dpi (Nazari et al. 2014). It is important to realize that VNN, which is synonymous to viral encephalopathy and retinopathy (VER) considered as a serious disease, notably occurs at the early development of fish; larval stages and juveniles may cause up to $100 \%$ mortality in larval stages at hatcheries when vertical transmission mode involved.

This virus was documented to be transmitted horizontally via waterborne from diseased to healthy fish within 4 days of contact (Nagasawa and Cruz-Lacierda 2004). The virus is also reported to be vertically transmitted from brood stocks to fingerlings; however, the mechanism of its transmission mode is still unclear. Recently, a study in marine hatchery producing hybrid grouper by Atirah-Khairiah et al. (2019) revealed a low rate of nervous necrosis virus (NNV) among the brood stocks with a prevalence of $50 \%$ in males and $33.3 \%$ in females which only detected at the early stage of the study period. Infected brood stocks however did not show any clinical sign indicating NNV infection. Throughout 1-year monitoring program from March 2016 to April 2017, two breeding attempts using different NNV status of eggs and sperms, NNV-positive giant grouper $(\mathrm{GG}) \times \mathrm{NNV}$-positive tiger grouper (TG) and NNVpositive GG $\times$ NNV-free TG, were performed. The breeding process resulted in a high prevalence of NNV between 60 and $100 \%$ in the hybrid grouper fry which was produced by at least one of the parents who were NNV-positive during the breeding (Atirah-Khairiah et al. 2019). The infected fry produced from NNV-positive brood stocks were detected positive as early as 5 days post-hatch. Nonetheless, the NNV-positive hybrid grouper showed no symptom of NNV infection. This suggested transmission of NNV is possible happens via vertical transmission. As a matter of fact, in another breeding trial using both NNV-free parents, there is no detection of NNV in fry produced (Atirah-Khairiah et al. 2019).

In view of disease protection, vaccination is a safe and effective preventive measure that use immunology discipline to stimulate fish immune system. An inactivated recombinant vaccine is commonly used as a safety measure, where the protein of the pathogen used to construct the recombinant vaccine cannot cause disease in fish but is able to provoke its immune response. Many studies had demonstrated a possible development of vaccine against betanodavirus; however, commercial VNN vaccine is still unavailable in the market. With this attention, PHARMAQ, a business of Zoetis, has developed the first and only commercially available vaccine against VNN in 2014 in Europe, named as ALPHA JECT micro 1 Noda. This injectable vaccine is a micro-dose emulsion of inactivated RGNNV for injection in European sea bass that shows high protection and duration of immunity for at least up to 1 year in their laboratories studies. Generally, most of fish vaccines are developed in inactivated form and many of them provide acceptable protection against disease. In this article, betanodavirus infection in Malaysia will be discussed as well as vaccination approaches that were done in previous studies will be reviewed.

\section{Betanodavirus in grouper}

Viral disease outbreak is the most serious issue among other pathogens as it may cause severe losses to the farmers up to $100 \%$ mortalities as well as to the economic. In most cases, larval and fingerlings are susceptible stages of this serious disease in grouper causing heavy mortalities. 
To date, there are two major viral infections of grouper which are viral nervous necrosis (VNN) and iridovirus (Ransangan et al. 2013; Razak et al. 2014; Sarath Babu et al. 2013). In recent years, a disease resembled to iridovirus had caused heavy losses to grouper aquaculture in Sabah, Malaysia, over a short period of time (Razak et al. 2014). A study was conducted to determine the status of iridovirus in grouper culture revealed detection of $15.6 \%$ of severely infected grouper and $17.4 \%$ of infected fish with asymptomatic carriers. Sequence analysis of two targeted genes, major capsid protein and ATPase, showed iridovirus isolates were clustered together under the genus Megalocytivirus (Iridoviridae) (Razak et al. 2014).

The VNN disease is caused by a significant pathogen named nervous necrosis virus. This virus, classed as a betanodavirus of the family Nodaviridae, pose a high risk towards global aquaculture production as it has been reported to strike more than 120 different farmed and wild fish as well as invertebrate species (Costa and Thompson 2016). Previous studies by Ransangan et al. (2013) had detected betanodavirus in four different fish species including humpback grouper, brown-marbled grouper, Asian sea bass, and golden pompano in Malaysia. There was a VNN outbreak in golden pompano culture in Langkawi Island, Malaysia, in April 2006 which later happened in November 2008 and January 2009 (Ransangan et al. 2013). In addition, a case was reported that brown grouper specimens sampled from a hatchery in Tuaran, Malaysia, in December 2008 and August 2009 were also detected VNN-positive (Ransangan et al. 2013). The re-occurrence of VNN outbreak was suspected due to the presence of carrier fish in the culture. However, the origin of betanodavirus in Malaysia still remains unknown. A study showed the virus strain could be circulated in one culture system lingering and has developed their significant identity. Phylogenetic tree analysis revealed strains detected in the recent study were closely related to each other and distinctively grouped from other NNV strain available in Genbank (Atirah-Khairiah et al. 2019).

Betanodavirus is responsible for causing a serious problem in hatchery-reared larvae and fingerlings of marine aquaculture. This virus has been further clustered into four genotypes, based on the RNA sequence of the T4 variable region of their capsid protein. Generally, betanodavirus is described after the species name of the host which they were isolated: striped jack nervous necrosis virus (SJNNV), tiger puffer nervous necrosis virus (TPNNV), barfin flounder nervous necrosis virus (BFNNV), and red-spotted grouper nervous necrosis virus (RGNNV) with a newly genotype proposed turbot betanodavirus strain (TNV) (Costa and Thompson 2016). These identified genotypes relatively correlate with three different serotypes that were identified by virus neutralization with polyclonal antibodies, different host, and the in vitro optimum growth temperature. Serotype A is referring to SJNNV with optimum growth temperature at $20-25^{\circ} \mathrm{C}$, while Serotype B is TPNNV that have optimum growth temperature at $20^{\circ} \mathrm{C}$. In addition, serotype $\mathrm{C}$ has two genotypes which are cold-water fish (BFNNV) and warm-water fish (RGNNV). Both have different optimum growth temperatures at $15-20{ }^{\circ} \mathrm{C}$ and $25-30{ }^{\circ} \mathrm{C}$ respectively (Mori et al. 2003; OIE 2016).

Betanodavirus or piscine nodavirus is a small non-enveloped icosahedral structure (25-30 $\mathrm{nm}$ ) which composed of two open reading frames (ORF) and single-stranded positive senses RNA, designated as RNA1 and RNA2. The RNA1 (3.1 kb in length) encodes an RNAdependent RNA polymerase (RdRps) for viral replication, whereas RNA2 (1.4 kb in length) encodes a viral capsid protein (CP) (Kim et al. 2015; KimJong et al. 2014; Nagasawa and Cruz-Lacierda 2004; Stathopoulou et al. 2018). An additional segment of RNA3 was also reported as generated sub-genomically from RNA1 which encodes the polypeptide B2 that inhibits an RNA interference system. However, RNA3 only exists in the infected cells but not wrapped into the viral particles (Bondad-Reantaso et al. 2005). 
Viral nervous necrosis disease can be transmitted via horizontal and vertical transmission mode. In open seawater, betanodavirus can survive at low temperature for a long time; thus, its transmission outside the host from the infected area to the other area could be caused by tidal currents or boats coming from the infected area (Juniar et al. 2018; OIE 2018). Betanodavirus is believed to invade the host via the intestinal epithelium and the peripheral nervous system before ending up at the central tissues which lead to fatality of the host. In a previous study, spotted wolfish (Anarhichas minor) were challenged with nodavirus via bath challenge showing an acute infection of VER at 4 to 8 weeks post-infection that could be diagnosed by histological immunohistochemistry (IHC) and reverse transcription polymerase chain reaction (RT-PCR). The findings revealed 52\% accumulated mortality in the challenge group. At 16 weeks post-infection, the virus was successfully re-isolated in SSN-1 cells from the survival fish indicating that nodavirus may retain its virulence and become persistent in infected fish (Johansen et al. 2003).

\section{Impact of VNN outbreak}

In an intensive rearing condition, farmers have estimated to lose at least $10 \%$ of the cultured population due to certain circumstances such as weather, water quality, and infectious disease. In the event of a disease outbreak by highly pathogenic viruses or bacteria, farmers may lose over $90 \%$ of their cultured species. Rimmer and Glamuzina (2019) reviewed a global grouper aquaculture production and noted the economic impacts of disease in Thailand and the Philippines. Smallscale farmers who reared grouper and barramundi in Thailand had reported a loss of about US $\$ 5000$ excluding the cost of treatment which varied between US\$5 and US\$500/year (Kanchanakhan et al. 2002; Rimmer and Glamuzina 2019). In another case study in the Philippines, a $26 \%$ occurrence of the disease was reported in nursery and grows out where mortalities happened without gross lesions (Somga et al. 2002). This situation also had affected the farmers' income.

Viral nervous necrosis disease was first documented three decades ago, in larvae and juveniles of hatchery-reared Japanese parrotfish (Oplegnathus fasciatus) (Yoshikoshi and Inoue 1990). In the report, mass mortalities had occurred, and in an examination through electron microscopic, numerous non-enveloped virus particles measured about $34 \mathrm{~nm}$ in diameter were found in the cytoplasm of affected neurons and glial cells. The nervous necrosis found in the tissues was suggested to be the significant reason of mortalities.

Presently, VNN has been detected in more than 50 fish species mainly in striped jack, grouper, and European sea bass (OIE 2016, 2018; Ransangan et al. 2013). Serious mortalities could not only be observed at the larval and juvenile stage but have also been reported in marketed-size fish such as sevenband grouper and European sea bass (OIE 2018). Little is known about the prevalence of the disease due to the lack of reporting from local farmers unless a case study or epidemiology studies are done on their farm. Although the outbreak of VNN disease could cause the highest mortalities up to $100 \%$ when larval stages are affected, farmers are optimistic and continue operating their farming activities (Chi et al. 1997; Le Breton et al. 1997; OIE 2016; Shetty et al. 2012).

\section{Diagnosis and disease prevention}

In aquaculture, water temperature is also being considered as a vital factor that affects the infection rate of disease. The clinical signs and optimum growth water temperature correlated 
to each other and was documented by in vitro studies (Okuno et al. 2001). Field diagnostic can be done by clinical signs and behavioral changes of the fish. The first observable sign of VNN outbreak is abnormal swimming behavior due to loss of equilibrium hence spiral swimming near the water surface (Yoshikoshi and Inoue 1990). Infected fish shows no external signs on the body surface or gills other than progression change of pigmentation and become darker in color indicating stress condition (OIE 2018; Shetty et al. 2012). Besides, the affected juvenile may develop bloated belly with abnormal behavior like lethargy and anorexia.

Conventionally, infection of VNN is confirmed histologically by the recognition of necrosis and vacuolization in the brain and retina incorporating with a positive IHC for nodavirus (Johansen et al. 2003). The spinal cord and brain of the affected fish showed vacuolation and pyknosis coincide with marked shrinkage and basophilia of affected cells (Yoshikoshi and Inoue 1990). Besides, enzyme-linked immunosorbent assays (ELISA) and RT-PCR have been developed as detection tools and conventionally, the virus can be observed via transmission electron microscopy (TEM) (Arimoto et al. 1992; Nishizawa et al. 1994; OIE 2016, 2018). In early studies, RT-PCR was used to generate partial sequences of the capsid protein gene of VNN viruses in order to compare and relate the fish nodaviruses. The results revealed nucleotide sequence of SJNNV capsid protein gene was almost similar with RNA2 of other fish nodaviruses found in previous studies (KimJong et al. 2014; Mori et al. 1992; Nishizawa et al. 1995, 1994; Stathopoulou et al. 2018).

Rapid expansion and intensification of marine aquaculture often lead to disease incidents. For the purpose of disease treatment and prevention, viral disease is difficult to control compared with bacterial disease due to the lack of anti-viral therapeutics and challenges for vaccine development (Shefat 2018). Good husbandry and biosecurity are vital keys of establishing a farming environment free from disease. Particularly, for maximizing aquatic animal health in aquaculture, optimal management on nutrition, genetics, and water quality are the critical parameters that need serious attention. In some disease cases, a diagnosis will be done to understand the causative agents. However, it is a challenge when the fish has stopped eating and treatment has no longer effective. Under these circumstances, prevention is a better option than disease treatment with drugs. Limited efficient treatment module to control viral disease occurrence posted a crucial demand for developing effective strategies to prevent the exposure of pathogen to fish culture.

\section{Vaccination}

Vaccination is one of disease management strategies that has been used to reduce the antibiotic usage in fish production to combat disease occurrence. Vaccine has its potential to prevent the development of disease by either blocking the pathogen from entering the host cells or preventing the establishment of pathology in the infected fish which may lead to the reason of mortality. The development of vaccine basically covers their efficacy based on relative percentage survival (RPS) and some studies showed promising results in reducing mortalities effectively in challenge trial giving medium to high protection level. Fish vaccination should be performed within the minimum period of exposure risk to pathogen and depending on the fish species. Other factors that play an important role in vaccination are temperature, stressor via the environment, stocking density, and fish handling during vaccination.

There are three common ways of fish immunization strategies which are by injection, immersion, and oral administration of vaccine (Muktar and Tesfaye 2016). Each strategy has 
its own advantages and disadvantages which vary on the level of protection and practicality. The choice of immunization strategies is very important in order to obtain high protection and is depending on the purpose and period of vaccination. To ensure good and effective protection, fish size, age, and a number of fish must be considered before deciding the choice of immunization strategy. In general, injection is the most potent way which can be used as mass vaccination method. Injectable vaccination is formulated with an oil-based or waterbased adjuvant which helps to further stimulate the immune system response. This method is a direct delivery of vaccine into the fish muscle (intramuscular) or fish body cavity (intraperitoneal). In spite of its cost-effective benefit, this method is impractical for smaller fish such as fry (Evensen 2009).

The second route of fish immunization is immersion. Immersion vaccination can be used for a large number of fish with an appropriate size such as fry or fingerlings. Immersion is an immunization strategy that commonly involves inactivated and live vaccines which allow mass vaccination at one time (Evensen 2009). By immersion, the vaccine composition is directly contacted to fish skin and gills which later will activate the fish adaptive immunity. Despite that, the immersion route may not have a prolonged protection. These two immunization ways are presently preferred as it can give high protection as primary route of fish vaccination.

The third route of immunization strategy is oral vaccination which allows direct administration of antigen via the digestive system of fish. Generally, vaccine will be incorporated with fish feed and the feeding schedule will be programmed according to the number of boosters needed. This immunization strategy has many advantages such as minimal stress on fish handling, all sizes of fish can be vaccinated, and the amount of labor can be reduced (Evensen 2009). Smaller fish like fry can be vaccinated via bioencapsulation and live feed. However, good protection of oral vaccination requires an understanding of palatability issues, antigen protection from digestion during passage through the stomach, and tolerogenic gut environment. Economically, this approach is known to be the best route in vaccination program that requires one or more booster immunization.

To date, only a few aquatic viral vaccines which are based on inactivated virus or recombinant proteins were commercialized and licensed such as infectious pancreatic necrosis (IPN), salmon pancreas disease virus, and, recently in 2014, ALPHA JECT micro 1 Noda for RGNNV by PHARMAQ. There are a number of studies focusing on different types of vaccine for $\mathrm{VNN}$ and had been tested in the laboratory such as recombinant protein, formalininactivated betanodavirus, DNA-based vaccines, and virus-like particle vaccines (Costa and Thompson 2016; Hølvold et al. 2014).

\section{Formalin-inactivated betanodavirus}

Formalin-killed or formalin-inactivated betanodavirus are produced by propagating the virus in large amounts which later subjected to inactivating agents such as formalin (Dadar et al. 2017). The formalin inactivation process may destroy the virus' ability to replicate and infectious state, but it preserves the intact virus form that could be recognized by immune system. Thus, immune response against betanodavirus in the host could be induced by introduction of formalin-inactivated betanodavirus via intramuscular (IM) vaccination.

Studies by Pakingking et al. (2009) had revealed a potential of formalin-inactivated RGNNV vaccine against VNN of Asian sea bass. A single injection of formalin-inactivated RGNNV had induced the production of neutralizing antibodies in sea bass at high antibody 
level from day 10 to day 116 with the highest antibody level recorded at day 60 postvaccination. In this study, there were no mortalities observed in both vaccinated and unvaccinated control fish when sea bass was challenged with RGNNV at day 54 post-vaccination (Pakingking et al. 2009). After the challenge, vaccinated group showed a low viral titer only in the brain of some fish on day 3 post-infection (p.i), and later, no virus was detected. In contrast, although no mortality was observed in unvaccinated group, a high viral titer was detected in the brain at day 3 p.i and day 5 p.i. However, the levels of virus were decreased at day 14 p.i and day 21 p.i.

A similar study was conducted using formalin-inactivated Philippine strain of RGNNV to induce potent immune response against intramuscular challenge of homologous virus in highly susceptible marine fish brown-marbled grouper, E. fuscoguttatus. The findings revealed the occurrence of substantial neutralizing antibody titer from day 15 to day 190 with mean titer ratios of 1:800 and 1:400 respectively, whereas the highest titer was recorded at day 60 postvaccination (1:5120) (Pakingking et al. 2010). Vaccinated groups demonstrated significantly lower mortalities rates compared with the unvaccinated group with high RPS values in the range of 86 to $100 \%$.

Recently, a study was conducted to evaluate the effectiveness of bivalent inactivated vaccine for VNN and grouper iridovirus (GIV) (Huang et al. 2017). The vaccine was administrated through intraperitoneal of orange spotted grouper as vaccinated group while the control group was mock-immunized with PBS. Detection rate of both viruses in egg specimens of vaccinated group was $10.5 \%$ before vaccination but was non-detectable after 1 month post-vaccination. In addition, 1-month post-vaccination analysis also showed the antibody titer ratios of anti-VNN in vaccinated group significantly increased (1:1810 to 1:5120) and are higher than that of the antibody titer of anti-GIV (1:57 to 1:320). This study suggested that vaccination could induce specific protective neutralizing antibody hence eliminating the infective antigens in fish (Huang et al. 2017).

Although formalin-inactivated vaccine may give promising results, the process to develop inactivated virus is too costly and needs extensive monitoring as $100 \%$ assurance of inactivation of virus is quite impossible.

\section{Live vaccine with betanodavirus}

Recently, a field test was conducted to evaluate the polyinosinic-polycytidylic acid (Poly(I:C)) immunization efficacy with live NNV conferring the protection in sevenband grouper, E. septemfasciatus (Thunberg) from VNN (Oh et al. 2012). This study involved Poly(I:C) immunization with live virus, followed by administration of polyinosinic-polycytidylic acid $[$ Poly(I:C)] that induced non-specific anti-viral state. In the study, three experiments were conducted by the administration of Poly(I:C) via intramuscular had revealed high protection levels with the survival rate of vaccinated group range in 93-99\% that lasted more than 10 months. The results indicated that Poly(I:C) immunization conferred the protection in fish against NNV infection and fish mortality could be reduced. However, this method requires a long time period and high expenses for administrative authorization of Poly(I:C) as fish medicine. Another shortcoming of this kind vaccination is infectious or pathogenic virus might be released to the environment due to improper practice in the field test.

Nishizawa et al. (2012) had demonstrated the potentiality of live NNV vaccine at low rearing temperature $\left(17^{\circ} \mathrm{C}\right)$ for sevenband grouper regardless of its infection method. In the study, the fish that was infected with NNV by immersion at $17{ }^{\circ} \mathrm{C}$ showed $93.3 \%$ survival rate, 
indicating a potential prevention method via live vaccine. The pathogenicity tests showed fish mortalities were reduced by decreasing rearing temperature ranging from 17 to $26^{\circ} \mathrm{C}$, and no mortality was recorded in fish reared at $17{ }^{\circ} \mathrm{C}$. The survivors from the 1 st NNV infection showed mortalities from 4-23.3\% during acclimatization to the optimum temperature of VNN $\left(26{ }^{\circ} \mathrm{C}\right.$ ); however, little or no mortality was observed in the 2 nd NNV infection in those survivors. Thus, this study speculated NNV is slowly multiplied at $17^{\circ} \mathrm{C}$ compared with their optimum temperature $26^{\circ} \mathrm{C}$, which resulted in lower NNV titer and far below the critical level of NNV. This could be the reason for the survival of fish reared at $17{ }^{\circ} \mathrm{C}$ that mounted a specific protective immune response against the disease. This study suggested that downregulating NNV multiplication by lowering the rearing temperature enables the control of VNN onset.

\section{DNA-based vaccine}

According to The Norwegian Biotechnology Advisory Board, DNA vaccination is defined as "the intentional transfer of genetic material (DNA or RNA) to somatic cells for the purpose of influencing the immune system" (Hølvold et al. 2014). Generally, DNA vaccine works in various ways to mimic the virus actions and requires the same cellular machinery to replicate and trigger host immune responses which were normally seen with viral infections. As an advantage, this type of vaccine may conserve the structure of transgenic antigen or protein as well as its antigenicity.

DNA-based vaccine encoding betanodavirus coat protein had met with the limited success in Atlantic halibut, turbot, and seas bass (Thiery et al. 2006). The early introduction of DNA vaccine of fish was in 1996 by immunized rainbow trout against infectious hematopoietic necrosis virus (IHNV). This approach has showed a promising protection to stimulate the host immune system of Atlantic salmon; however, plasmid carrying the Atlantic halibut nodavirus coat protein gene failed to induce protective immune response against VNN challenge (Lorenzen et al. 1999; Sommerset et al. 2005; Thiery et al. 2006). A study was conducted by Lorenzen et al. (1999) to evaluate the potential of DNA vaccine against viral haemorrhagic septicaemia (VHS) in rainbow trout. At week 8 post-vaccination, fish was challenged against virus isolates where no protection was observed following vaccination with plasmid encoding VHS virus nucleocapsid protein gene. Limited documentation on DNA vaccines in fish has yet yielded sufficient results in terms of its protection efficacy (Hølvold et al. 2014).

\section{Recombinant vaccine of betanodavirus}

Recombinant protein vaccines are one of the best reassuring control measures to reduce economic losses due to mass mortality in marine aquaculture caused by VNN disease. Recently, a study on recombinant vaccines used the viral capsid protein gene expressed as a protein with a 6-histidine tag in Escherichia coli BL21. Asian sea bass was immunized with purified polyclonal antiserum (r-FNCP42) and later challenged with nodavirus by intramuscular injection. The results of the study showed RPS value at $76 \%$ in the vaccinated sea bass (Vimal et al. 2014).

In a study by Kim et al. (2015), recombinant viral coat protein of sevenband grouper nervous necrosis (NNV) was expressed using cell-free protein synthesis (CFPS) system. The CFPS system is derived from crude cell extracts for protein expression and has few advantages compared with the traditional cell-based approach such as easy modification of reaction 
conditions depending on the targeted protein. In addition, with the absence of a cell wall, this system can easily be monitored and direct manipulation of the protein synthesis process could be improved.

This recombinant NNV coat protein was administrated into sevenband grouper at different doses followed by challenge test using NNV. Findings showed a high protection of immunized fish with lower cumulative mortality $(10 \%)$ compared with non-immunized group that reached $70 \%$ cumulative mortality after day 5 post-challenge. Although the effectiveness of this method depends on the dose administered, this study had proposed a new approach to develop a recombinant vaccine against betanodavirus infection for sevenband grouper (Kim et al. 2015).

A previous study had demonstrated an oral NNV vaccine composed of Artemia-encapsulated recombinant E. coli expressing the NNV capsid protein gene. Due to the small size of grouper larvae and their sensitivity to handling, the NNV VP-containing Artemia was used as the vaccination approach towards grouper larvae. After the challenge with the virus, vaccinated larvae achieved a relative percentage survival rates of $64.2 \%$ and $69.5 \%$, indicating the oral vaccine could effectively immunize the grouper larvae (Lin et al. 2007). Recombinant vaccines have advantages such as low production cost and safety. Moreover, E. coli is known as the most beneficial host for recombinant protein expression (Kim et al. 2015).

\section{Conclusions}

A current scenario demonstrated that VNN carrier brood stock was found to be a source of inoculum for betanodavirus to their offspring. Thus, strict husbandry management in hatchery such as pre- and post-spawning screening of brood stock for VNN is important. Mass mortalities that happened at larval stages of grouper culture were due to vertical transmission of VNN which warrants immediate attention for promising disease control strategies such as new vaccine which is very crucial to control VNN disease. A recent study had revealed VNN in grouper brood stock in a hatchery system is a type of persistent infection (Atirah-Khairiah et al. 2019). This scenario might be an important source of disease outbreak especially for VNN disease that could cause up to $100 \%$ mortality in fry production during breeding process. Vertical transmission can easily happen if either of the parent is NNV-positive (Atirah-Khairiah et al. 2019).

Many studies were done to develop vaccination protocol for VNN but somehow, there are still no commercial vaccines available for VNN where aquaculture industry currently shows an urgent need for an effective prevention tools to combat this disease problem. This is due to difficulties to vaccinate fry and fingerlings which are the most susceptible size of VNN infection by commercial vaccines that use injection method and expensive cost of vaccine production. As has been noted, the recent commercialized injectable vaccine for RGNNV of European sea bass, ALPHA JECT micro 1 Noda, also recommends dose for fish with a minimum weight of $12 \mathrm{~g}$.

Another problem faced in vaccine development is the different host specificities among genotypic variants (Tanaka et al. 2001). Nonetheless, laboratory trial and field trial vaccine protection are various leads to limited commercialized VNN vaccine due to stocking density, natural environment, uncontrolled temperature, and the management farming system in the farm operation. Based on the previous studies, VNN can be transmitted 4 days after contact via horizontal transmission and can be detected on day 5 post-hatching via vertical transmission. As has been noted that VNN could be possibly transmitted vertically, vaccination of brood 
stocks is crucial. Due to the fact that some of grouper brood stocks in Malaysia were latently infected by $\mathrm{NNV}$, the best time for vaccination needs to be determined in order to trigger protection before the breeding process begins (Atirah-Khairiah et al. 2019).

Overall, the most suitable route of vaccination for larvae is immersion as the size of grouper larvae is too small. In addition, oral vaccination via bioencapsulation of vaccine in live feed can be used on grouper larvae to trigger their early immune response. Nevertheless, more studies on VNN disease need to be carried out to determine the best way for fish vaccination either to use the brood stocks or its fry to protect them from VNN disease occurrence.

\section{Compliance with ethical standards}

Conflict of interest The authors declare that they have no conflict of interest.

Ethical approval This article does not contain any studies with animals performed by any of the authors.

\section{References}

AFS (2016. Annual Fisheries Statistic. Department of Fisheries, Ministry of Agriculture \& Agro-Based Industry, Malaysia

Arimoto M, Mushiake K, Mizuta Y, Nakai T, Muroge K, Furusawa I (1992) Detection of striped jack nervous necrosis virus (SJNNV) by enzyme-linked immunosorbent assay (ELISA). Fish Pathol 27(4):191-195. https://doi.org/10.3147/jsfp.27.191

Atirah-Khairiah A, Amal MNA, Zamri-Saad M, Murni M, Azila A, Sufian M, Nik-Haiha NY (2019) Prevalence, risk factors and transmission of nervous necrosis virus in a hatchery producing hybrid grouper (Epinephelus lanceolatus $\times$ E. fuscoguttatus) fry. Pertanika J Trop Agric Sci 42(1):125-138 Retrieved from http://psasir. upm.edu.my/id/eprint/67326/1/09JTAS-1488-2018.pdf. Accessed 6 May 2019

Bondad-Reantaso MG, Subasinghe RP, Arthur JR, Ogawa K, Chinabut S, Adlard R, Tan Z, Shariff M (2005) Disease and health management in Asian aquaculture. Vet Parasitol 132(3-4):249-272. https://doi. org/10.1016/j.vetpar.2005.07.005

Chi SC, Lo CF, Kou GH, Chang PS, Peng SE, Chen SN (1997) Mass mortalities associated with viral nervous necrosis (VNN) disease in two species of hatchery-reared grouper, Epinephelus fuscogutatus and Epinephelus akaara (Temminck \&amp; Schlegel). J Fish Dis 20(3):185-193. https://doi.org/10.1046 jj.1365-2761.1997.00291.x

Costa JZ, Thompson KD (2016) Understanding the interaction between Betanodavirus and its host for the development of prophylactic measures for viral encephalopathy and retinopathy. Fish Shellfish Immunol 53: 35-49. https://doi.org/10.1016/j.fsi.2016.03.033

Dadar M, Dhama K, Vakharia VN, Hoseinifar SH, Karthik K, Tiwari R, Khandia R, Munjal A, Salgado-Miranda C, Joshi SK (2017) Advances in aquaculture vaccines against fish pathogens: global status and current trends. Rev Fish Sci Aquac 25(3):184-217. https://doi.org/10.1080/23308249.2016.1261277

Evensen Ø (2009) Development in fish vaccinology with focus on delivery methodologies, adjuvants and formulations. In: Basurco B, Roger C (eds) The use of veterinary drugs and vaccines in Medditerranien Aquacultre. Zaragoza: CIHEAM (Options Mediterraneennes; Vol A pp 177-186) Retrieved from http://om. ciheam.org/om.pdf/a86/00807010.pdf

Hølvold LB, Myhr AI, Dalmo RA (2014) Strategies and hurdles using DNA vaccines to fish. Vet Res 45:1-11. https://doi.org/10.1186/1297-9716-45-21

Huang S-M, Cheng J-H, Tu C, Chen T-I, Lin C-T, Chang S-K (2017) A bivalent inactivated vaccine of viral nervous necrosis virus and grouper iridovirus applied to grouper broodfish (Epinephelus coioides) reduces the risk of vertical transmission. Taiwan Vet J 43(03):171-176. https://doi.org/10.1142/s1682648517500032

Johansen R, Amundsen M, Dannevig B, Sommer A (2003) Acute and persistent experimental nodavirus infection in spotted wolffish Anarhichas minor. Dis Aquat Org 57(1-2):35-41. https://doi.org/10.3354 /dao057035 
Juniar E, Kurniasih K, Sumiarto B (2018) Risk factors of a viral nervous necrosis disease in grouper (Epinephelus spp.) cultured in Bintan district, Indonesia. Vet World 11(11):1558-1563. https://doi. org/10.14202/vetworld.2018.1558-1563

Kanchanakhan S, Chanratchakool P, Direkbusarakom S (2002) The impact of disease in small-scale coastal cagefish culture in Thailand. In: Arthur JR, Phillips MJ, Subasinghe RP, Rean- taso MB, MacRae IH (eds) FAO Fisheries Techical Paper, 406 (Primary aquatic animal health care in rural, small-scale, aquaculture development). pp 203-206

Kim J-O, Kim J-O, Kim W-S, Oh M-J (2015) Development of a recombinant protein vaccine based on cell-free protein synthesis for sevenband grouper Epinephelus septemfasciatus against viral nervous necrosis. $J$ Microbiol Biotechnol 25(10):1761-1767. https://doi.org/10.4014/jmb.1507.07004

KimJong Oh, Sih KW, Cho JK, Kim KM, Son MH, Oh MJ (2014) Complete genome sequence of nervous necrosis virus isolated from sevenband grouper (Epinephelus septemfasciatus) in South Korea. 2(6)2014. https://doi.org/10.1128/genomeA.01264-14.Copyright

Le Breton A, Grisez L, Sweetman J, Ollevier F (1997) Viral nervous necrosis (VNN) associated with mass mortalities in cage-reared sea bass, Dicentrarchus labrax (L.). J Fish Dis 20(2):145-151. https://doi. org/10.1046/j.1365-2761.1997.00284.X

Lin C-C, Lin JH-Y, Chen M-S, Yang H-L (2007) An oral nervous necrosis virus vaccine that induces protective immunity in larvae of grouper (Epinephelus coioides). Aquaculture 268(1):265-273. https://doi.org/10.1016 /j.aquaculture.2007.04.066

Lorenzen N, Lorenzen E, Einer-Jensen K, Heppell J, Davis HL (1999) Genetic vaccination of rainbow trout against viral haemorrhagic septicaemia virus: small amounts of plasmid DNA protect against a heterologous serotype. Virus Res 63(1-2):19-25 Retrieved from http://www.ncbi.nlm.nih.gov/pubmed/10509712. Accessed 8 August 2018

Mori K, Nakai T, Muroga K, Arimoto M, Mushiake K, Furusawa I (1992) Properties of a new virus belonging to nodaviridae found in larval striped jack (Pseudocaranx dentex) with nervous necrosis. Virology 187(1):368371 Retrieved from http://www.ncbi.nlm.nih.gov/pubmed/1736540

Mori K, Mangyoku T, Iwamoto T, Arimoto M, Tanaka S, Nakai T (2003) Serological relationships among genotypic variants of betanodavirus. Dis Aquat Org 57(1-2):19-26. https://doi.org/10.3354/dao057019. Accessed 8 August 2018

Muktar Y, Tesfaye S (2016) Present status and future prospects of fish vaccination: a review. J Vet Sci Technol 07(02). https://doi.org/10.4172/2157-7579.1000299

Muroga K (2001) Viral and bacterial diseases of marine fish and shellfish in Japanese hatcheries. Aquaculture 202(1-2):23-44. https://doi.org/10.1016/S0044-8486(01)00597-X

Nagasawa K, Cruz-Lacierda ER (2004) Diseases of cultured groupers. In: SEAFDEC Aquaculture Department. (p. 81). Retrieved from http://www.amazon.co.uk/Diseases-Cultured-Groupers-KazuyaNagasawa/dp/9718511709/ref=sr_1_1 ?ie=UTF $8 \& q i d=1400307616 \& \mathrm{sr}=8-1 \& \mathrm{keywords}=$ diseases+of+cultured+groupers. Accessed 8 August 2018

Nazari A, Hassan MD, Bovo G, Zorriehzahra MJ, Azmi TI, Arshad SS (2014) Pathogenicity of viral nervous necrosis virus for Guppy fish, Poecilia reticulata. Iran J Fish Sci 13(1):168-177

Nishizawa T Gye HJ, Takami I, Oh MJ (2012). Potentiality of a live vaccine with nervous necrosis virus (NNV) for sevenband grouper Epinephelus septemfasciatus at a low rearing temperature. Vaccine, 30(6):1056-1063. https://doi.org/10.1016/j.vaccine.2011.12.033

Nishizawa T, Mori K-I, Nakai T, Furusawa I, Muroga K (1994) Polymerase chain reaction (PCR) amplification oí RNA oí striped jack nervous necrosis virus (SJNNV). Dis Aquat Org 1:103-107. https://doi.org/10.3354/dao018103

Nishizawa T, Mori K-I, Furuhashi M, Nakai T, Furusawa I, Muroga K (1995) Comparison of the coat protein genes of five fish nodaviruses, the causative agents of viral nervous necrosis in marine fish. J Gen Virol 76 ( Pt 7:1563-1569. https://doi.org/10.1099/0022-1317-76-7-1563

Oh MJ, Takami I, Nishizawa T, Kim WS, Kim CS, Kim SR, Park MA (2012) Field tests of Poly(I:C) immunization with nervous necrosis virus (NNV) in sevenband grouper, Epinephelus septemfasciatus (Thunberg). J Fish Dis 35(3):187-191. https://doi.org/10.1111/j.1365-2761.2011.01334.x

OIE (2016) Viral encephalopathy and retinopathy. Manual of Diagnostic Tests for Aquatic Animals, (May 2013), pp 1-20

OIE (2018) Viral encephalopathy and retinopathy. Manual of Diagnostic Tests for Aquatic Animals, pp. 1-20.

Okuno T, Mori K, Iwamoto T, Mise K, Nakai T, Arimoto M (2001) Establishment of an infectious RNA transcription system for Striped jack nervous necrosis virus, the type species of the betanodaviruses. J Gen Virol 82(11):2653-2662. https://doi.org/10.1099/0022-1317-82-11-2653

Pakingking R, Seron R, Dela Peña L, Mori K, Yamashita H, Nakai T (2009) Immune responses of Asian sea bass, Lates calcarifer Bloch, against an inactivated betanodavirus vaccine. J Fish Dis 32(5):457-463. https://doi.org/10.1111/j.1365-2761.2009.01040.x 
Pakingking R, Bautista NB, de Jesus-Ayson EG, Reyes O (2010) Protective immunity against viral nervous necrosis (VNN) in brown-marbled grouper (Epinephelus fuscoguttatus) following vaccination with inactivated betanodavirus. Fish Shellfish Immunol 28(4):525-533. https://doi.org/10.1016/j.fsi.2009.12.004

Ransangan J, Manin BO, Lal TMM, Lu KC, Sade A, Azila A (2013) Betanodavirus infection in marine fish aquaculture in Malaysia. Res J Anim Vet Fish Sci 1(7):10-15

Razak AA, Ransangan J, Sade A (2014) First report of megalocytivirus (Iridoviridae) in grouper culture in Sabah, Malaysia. Int J Curr Microbiol Appl Sci 3(3):896-909

Rimmer MA, Glamuzina B (2019) A review of grouper (Family Serranidae: Subfamily Epinephelinae) aquaculture from a sustainability science perspective. Rev Aquac 11(1):58-87. https://doi.org/10.1111/raq.12226

Sarath Babu V, Abdul Majeed S, Nambi KSN, Taju G, Madan N, Sundar Raj N, Sahul Hameed AS (2013) Comparison of betanodavirus replication efficiency in ten Indian fish cell lines. Arch Virol 158(6):13671375. https://doi.org/10.1007/s00705-013-1617-7

Shefat SHT (2018) Vaccines for use in finfish aquaculture. Acta Sci Pharm Sci 2(11):15-19

Shetty M, Maiti B, Shivakumar Santhosh K, Venugopal MN, Karunasagar I (2012) Betanodavirus of marine and freshwater fish: distribution, genomic organization, diagnosis and control measures. Indian J Virol 23(2): 114-123. https://doi.org/10.1007/s13337-012-0088-x

Somga JR, Somga SS, Reantaso M (2002) Impacts of disease on small-scale grouper culture in the Philippines. In: Arthur JR, Phillips MJ, Subasinghe RP, Reantaso MB, MacRae IH (eds) FAO Fisheries Techical Paper, pp. 207-214

Sommerset I, Skern R, Biering E, Bleie H, Fiksdal IU, Grove S, Nerland AH (2005) Protection against Atlantic halibut nodavirus in turbot is induced by recombinant capsid protein vaccination but not following DNA vaccination. Fish Shellfish Immunol 18(1):13-29. https://doi.org/10.1016/j.fsi.2004.03.006

Stathopoulou P, Rafailidou N, Tzokas K, Batargias C, Tsiamis G (2018) Near-complete genome sequence of a fish nervous necrosis virus isolated from a clinical disease outbreak in farm-reared bream sparus aurata in Spain. Genome Announc 6(1):1-2. https://doi.org/10.1128/genomeA.01392-17

Tanaka S, Mori K, Arimoto M, Iwamoto T, Nakai T (2001) Protective immunity of sevenband grouper, Epinephelus septemfasciatus Thunberg, against experimental viral nervous necrosis. J Fish Dis 24(1):1522. https://doi.org/10.1046/j.1365-2761.2001.00259.x

Thiery R, Cozien J, Cabon J, Lamour F, Baud M, Schneemann A (2006) Induction of a protective immune response against viral nervous necrosis in the European sea bass Dicentrarchus labrax by using betanodavirus virus-like particles. J Virol 80(20):10201-10207. https://doi.org/10.1128/JVI.01098-06

Vimal S, Madan N, Farook MA, Nambi KSN, Majeed SA, Rajkumar T, Venu S, Thirunavukkarasu AR, Hameed ASS (2014) Production of recombinant vaccine using capsid gene of nodavirus to protect Asian sea bass, Lates calcarifer (Bloch, 1790). Aquaculture 418-419:148-154. https://doi.org/10.1016/j. aquaculture.2013.10.017

Yoshikoshi K, Inoue K (1990) Viral nervous necrosis in hatchery-reared larvae and juveniles of Japanese parrotfish, Oplegnathus fasciatus (Temminck \&amp; Schlegel). J Fish Dis 13(1):69-77. https://doi. org/10.1111/j.1365-2761.1990.tb00758.x

Publisher's note Springer Nature remains neutral with regard to jurisdictional claims in published maps and institutional affiliations. 